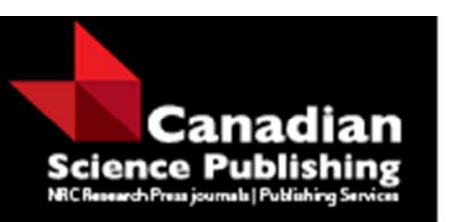

Canadian Journal of Civil Engineering Revue canadienne de génie civil

\title{
Regulations Governing the Operation of Longer Combination Vehicles in Canada
}

\begin{tabular}{|r|l|}
\hline Journal: & Canadian Journal of Civil Engineering \\
\hline Manuscript ID & cjce-2017-0050.R1 \\
\hline Manuscript Type: & Article \\
\hline Date Submitted by the Author: & 12-Jun-2017 \\
\hline $\begin{array}{r}\text { Complete List of Authors: } \\
\begin{array}{r}\text { Is the invited manuscript for } \\
\text { consideration in a Special } \\
\text { Issue? : }\end{array}\end{array}$ & $\begin{array}{l}\text { Nood, Steven; University of Manitoba, Department of Civil Engineering } \\
\text { Regehr, Jonathan; University of Manitoba, Department of Civil Engineering }\end{array}$ \\
\hline $\begin{array}{r}\text { Keyword: } \\
\text { geometric design }\end{array}$ & $\begin{array}{l}\text { longer combination vehicles (LCVs), truck regulations, traffic operations, } \\
\text { geomens }\end{array}$ \\
\hline
\end{tabular}

\section{SCHOLARONE \\ Manuscripts}


2

3

4

\section{Regulations Governing the Operation of Longer Combination Vehicles in Canada}

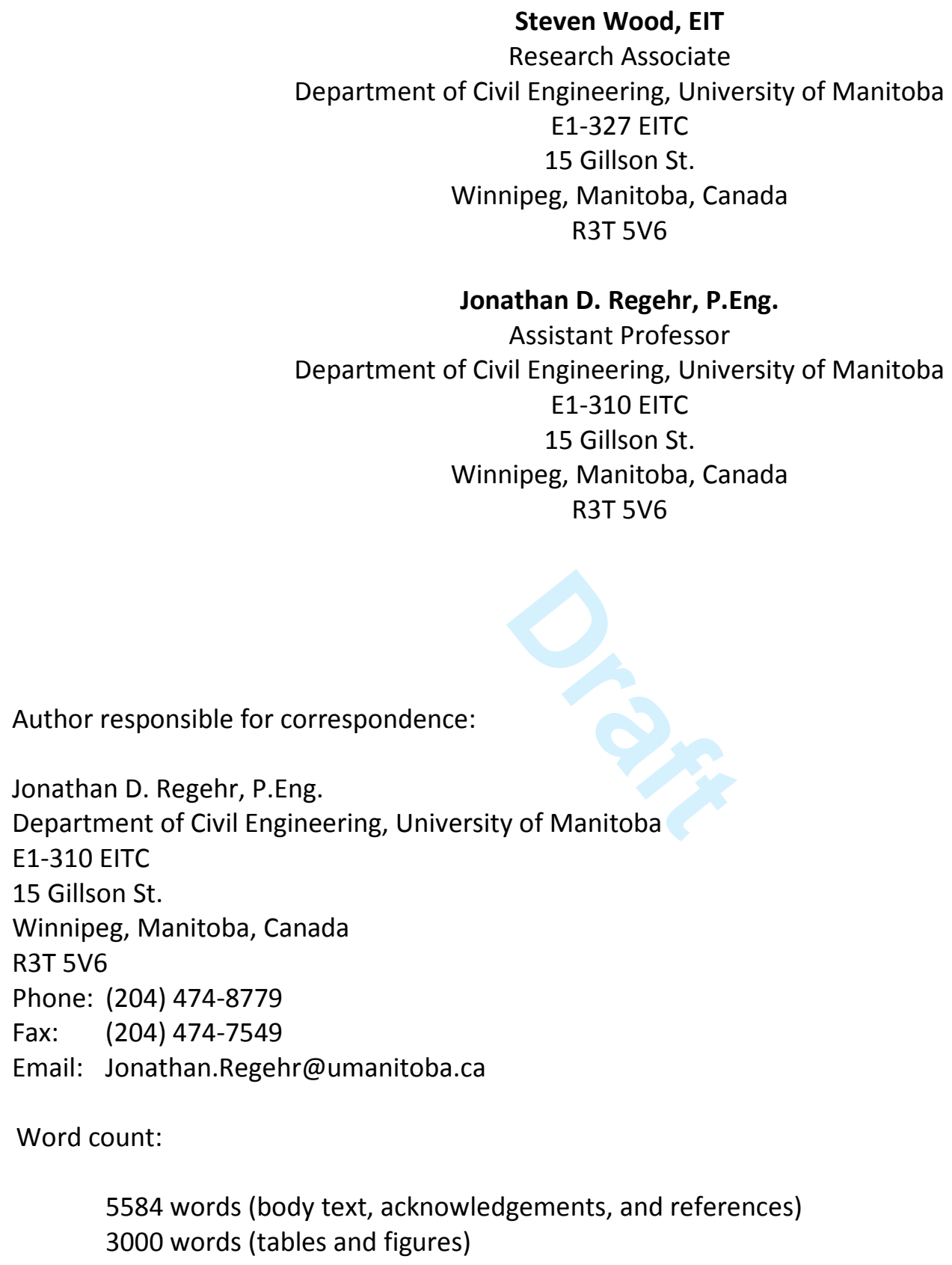




\section{Abstract}

42 The permits governing longer combination vehicle (LCV) activity in Canada aim to leverage LCV

43 productivity advantages relative to other truck configurations while subjecting LCV operations to

44 stringent regulatory controls. As of 2016 , nine of the 13 provinces/territories permit LCV operations on a

45 17,000-km highway network. This article synthesizes LCV regulations in these jurisdictions within five

46 categories: a) carrier permit requirements, b) truck size and weight limits, c) equipment requirements,

47 d) operating conditions, and e) driver qualifications. While jurisdiction-specific differences remain, the

48 synthesis reveals regulatory uniformity at the regional level. The article identifies how these regulations

49 influence highway design, operations, and management decisions concerning the accommodation of

50 LCV performance characteristics, the spatial and temporal control of LCV operations, the eligibility of

51 drivers and carriers to operate LCVs, and opportunities for regulatory harmonization. As LCV activity

52 increases, the need to formally consider the characteristics of LCVs within these decisions becomes

53 more apparent.

\section{$54 \quad$ Key Words}

55 Longer combination vehicles, truck regulations, traffic operations, geometric design 


\section{Introduction}

In Canada, longer combination vehicles (LCVs) are truck configurations consisting of a tractor

59 and two or three trailers or semi-trailers with a combined length greater than $27.5 \mathrm{~m}$. The movement of

LCVs on Canadian highways occurs pursuant to operating permits issued to trucking companies (carriers)

61 by public transportation agencies. These permits allow LCVs to operate beyond basic truck length limits

62 but also define a regulatory environment which uniquely governs LCV travel. Because of their extended length, LCVs offer a transportation productivity advantage relative to other truck configurations, particularly when hauling low-density freight (Regehr, Montufar, Clayton 2009a).

LCVs have been operating in Canada for nearly 50 years. In this time, the development and application of LCV regulations in Canada have evolved considerably as regulators respond to increasing

67 demand for LCV travel while simultaneously striving to achieve the objectives of safety, productivity, infrastructure protection, and environmental sustainability. From a civil engineering perspective, there is a need to understand the implications these regulations have on how highway systems are planned, designed, operated, and managed. Existing research, such as the work by Burns (1983), Nix (1995), Ray

71 Barton Associates Ltd. (2003), Regehr (2009), and Woodrooffe et al. (2010), provides valuable insights

72 into the regulation and operation of LCVs at jurisdictional or regional scales. However, as the scope and magnitude of LCV operations continue to expand, the need to benchmark the regulations currently governing these operations from a national perspective is evident. This article aims to accomplish this, thereby providing a novel contribution to future LCV-related policy decisions within Canada and beyond. Specifically, this article has three main objectives. First, to set the context for the review and

77 synthesis of LCV regulations, the article provides an overview of the evolution of LCV operations in

78 Canada. The overview describes the details of common LCV configurations operating in Canada and the 
historical evidence of major network changes that have impacted the utilization of LCVs across the

81 country.

Second, the article reviews and synthesizes the regulations that currently govern LCV operations in Canada. Regulatory details are provided within five categories: carrier permit requirements, truck size and weight limits, equipment requirements, operating conditions, and driver qualifications. The scope of the synthesis is limited to the regulations in effect in the provinces/territories that currently permit LCV operations. Regulations in urban jurisdictions were not specifically investigated, though some

87 information about urban LCV operations (e.g., network access provisions) is included in the provincial/territorial permits. Additionally, peripheral topics such as the development and rationale of LCV permit fees, LCV collision reporting procedures, and certain details about relevant truck size and weight limits are beyond the scope of this article. operations. Vehicle specifications, the control of LCV operations spatially and temporally, and driver and carrier performance criteria directly influence design and operations decisions. When regulatory harmonization improves network connectivity, the potential increase in LCV activity further affects these decisions. The regulations governing LCV operations also influence pavement and bridge design and maintenance; however, these issues will not be discussed in this article.

\section{Overview of LCV Operations in Canada}

98 There are three common LCV configurations in Canada (Table 1): a) turnpike doubles (turnpikes), which consist of a tractor, one 16.2-m (53-ft) semi-trailer, and one 16.2-m (53-ft) trailer or semi-trailer, and are subject to overall length limits between 40.0 and 41.0 m; b) Rocky Mountain doubles (Rockies), which consist of a tractor, one $16.2-\mathrm{m}(53-\mathrm{ft})$ semi-trailer, and one $8.5-\mathrm{m}(28.5-\mathrm{ft})$ trailer or semitrailer, and are normally subject to overall length limits between 31.0 and $32.5 \mathrm{~m}$; and c) triple trailer combinations 
103 (triples), which consist of a tractor, one 8.5-m (28.5-ft) semi-trailer, and two 8.5-m (28.5-ft) trailers or 104 semi-trailers, and are subject to overall length limits between 35.0 and $41.0 \mathrm{~m}$. LCVs are not normally 105 permitted to operate beyond normal axle or gross vehicle weight (GVW) limits.

As of 2016, nine of 13 provinces/territories permit some form of LCV operations. These include: British Columbia, Alberta, Saskatchewan, Manitoba, Northwest Territories, Ontario, Québec, New Brunswick, and Nova Scotia. Many urban jurisdictions also permit LCV operations on selected routes to provide access to shippers, receivers, and carrier terminals.

Fig. 1 and Fig. 2 show the highways on which LCV operations are permitted in western and eastern Canada, respectively, as of August 2016. In Alberta, Saskatchewan, and Manitoba, all three LCV configurations are permitted on divided highways (with four or more lanes) and a limited number of undivided routes. Only Rockies are permitted on undivided roads that meet specified geometric criteria, 114 primarily to provide access to key freight origins and destinations. In these three provinces, the LCV network connects all major urban centres (i.e., Calgary and Edmonton, Alberta, Regina and Saskatoon, Saskatchewan, and Winnipeg, Manitoba). Additionally, the undivided highway network provides

117 connections to rural and northern population centres such as Prince Albert, Saskatchewan and into the 118 Northwest Territories (Di Cristoforo et al. 2012). In British Columbia, LCV operations occur on a limited network in the southwest part of the province and on Vancouver Island. No connection exists between the LCV network in British Columbia and the network in the Prairie Provinces.

The eastern Canadian provinces (Fig. 2) permit the operation of turnpikes on a network that

122 extends throughout southeastern Ontario and southeastern Québec, and includes selected routes in 123 New Brunswick and Nova Scotia. Rockies and triples are not permitted on these routes. As in the Prairie 124 Provinces, this network provides regional connectivity between major urban centres in Ontario and 125 Québec (i.e., Windsor, Toronto, and Ottawa, Ontario, and Montréal and Québec City, Québec) and in 126 New Brunswick and Nova Scotia (i.e., Fredericton, Saint John, and Moncton, New Brunswick, and Halifax, 
127 Nova Scotia). No connection currently exists between these two regional networks, although available

128 evidence indicates that construction on the twinning of this $40-\mathrm{km}$ gap is scheduled to commence in 1292017 (Québec Portal 2015). Canada's current LCV network has evolved considerably, presumably in response to the rising demand for inter-provincial trucking service. Table 2 summarizes the extent of the LCV highway network in each jurisdiction in selected years since 1969. Overall, the network has grown from an initial extent of $300 \mathrm{~km}$ (all in Alberta) to its current reach of approximately 17,000 km across nine provinces/territories.

134 For reference, the current extent of Canada's LCV network is nearly half the total distance comprising 135 Canada's National Highway System (Transport Canada 2011). Key network-related developments follow 136 (Nix 1995; New Brunswick Communications 2005; Truck News 2008; McCormick 2009; Regehr 2009;

137 Truck News 2011; Di Cristoforo et al. 2012):

- 1969: Alberta establishes a test program for triples between Calgary and Edmonton, marking the first documented operation of LCVs in Canada.

- Circa 1982: Alberta, Saskatchewan, and Manitoba permit certain types of LCVs on limited intraprovincial networks.

- Circa 1988: Rockies are permitted on selected undivided routes in Alberta, Saskatchewan, Manitoba, and the Northwest Territories, providing regional interconnectivity. Québec permits the operation of LCVs on four-lane divided highways. turnpikes between all major urban centres in the Prairie Provinces. British Columbia commences a pilot project for Rocky operations on a portion of the Coquihalla Highway. Similarly, Nova 
Scotia launches its own pilot program with the view to provide connectivity with the New Brunswick network.

- 2009: Ontario initiates a pilot program for the operation of turnpikes on selected 400 -series highways. (This program was made permanent in 2011.)

Despite these network-related developments, there is limited publicly-available evidence of the growth of LCV travel across Canada. Regehr, Montufar, and Clayton (2009a) compile historical truck traffic data (1970 to 2005) from a site on the Trans Canada Highway west of Winnipeg, Manitoba. These data capture several changes in the articulated truck fleet mix, including the penetration of LCVs into the articulated truck fleet prior to 2005 resulting from the gradual regionalization of the LCV network throughout the Prairie Provinces. Roadside survey data collected by the University of Manitoba Transport Information Group (UMTIG) in 2013, 2015, and 2016 indicate growth in the proportion of LCVs within the articulated truck fleet at this location, reaching a fleet penetration of more than 10 percent in 2013. Since 2013, the proportional representation of LCVs within the fleet has declined, although the absolute volume of LCVs at this site has remained roughly constant. Di Cristoforo et al. (2012) further reveal that this overall growth is nearly all attributable to the adoption of turnpike doubles, as the operation of Rockies and triples at this location declined to nominal levels by 2009 . Some empirical evidence of the system-wide growth in Canadian LCV travel is also available in the literature. Based on a survey of LCV carriers, Nix (1995) estimates that total annual LCV travel in Alberta, Saskatchewan, Manitoba, and Québec (the four provinces that permitted LCVs at the time) amounted to 71 million kilometres. In Alberta, Regehr et al. (2009b) estimate that LCVs travelled a total of 256 million kilometres in the years 1999 to 2005, inclusive, an average of about 37 million kilometres per year. More recently, Regehr (2009) estimates total LCV travel in the province to be 39 million kilometres in 2006. In Ontario, Truck News (2011) reports that LCVs made 21,000 trips and travelled a 
174 total of 6.6 million kilometres during its pilot program (between 2009 and 2011). In 2014, carriers

175 participating in Ontario's LCV program travelled over 11 million kilometres in 36,000 one-way trips

176 (Ontario Ministry of Transportation 2016).

177 As the LCV network expands and LCV operations grow, the need for inter-jurisdictional

178 regulatory harmonization has become apparent. The recent (2012) memorandum of understanding

179 (MoU) signed by the four western provinces (i.e., British Columbia, Alberta, Saskatchewan, and

180 Manitoba) demonstrates a desire to create a seamless operating environment for inter-jurisdictional

181 LCV activity. A similar MoU has recently been signed in 2016 by the four eastern provinces (i.e., Ontario,

182 Québec, New Brunswick, and Nova Scotia) with similar intent. Despite progress towards regulatory

183 harmonization, regional and jurisdiction-specific regulatory differences remain.

\section{Synthesis of Current LCV Regulations in Canada}

185 This section synthesizes Canadian LCV regulations within five categories.

1. Carrier permit requirements

2. Truck size and weight limits

3. Equipment requirements

4. Operating conditions

5. Driver qualifications

191 Findings stem from a comprehensive review of each jurisdiction's LCV permit documentation,

192 supplemented as needed by direct correspondence with officials responsible for these regulations. The 193 review is considered current as of August 2016. The following sections present regulatory details in 194 tabular form to facilitate identification of commonalities and differences. 


\section{Carrier Permit Requirements}

Table 3 summarizes the general permit requirements for LCV carriers in Canada. There is

considerable harmonization of these requirements across Canada. In all jurisdictions, a carrier must

obtain a permit prior to operating LCVs; this permit is usually renewable on an annual basis. To renew a

permit, carriers must abide by all permit conditions and meet safety-related requirements. In terms of

limited to a specific pre-approved route within the province's LCV network, while permits in western

\section{Truck Size and Weight Limits}

Table 4 summarizes certain truck size and weight limits for LCVs operating in Canada. Principal observations about these limits follow:

- Turnpikes are the most widely permitted LCV configuration in Canada, with operations permitted in all jurisdictions except the Northwest Territories. In contrast, only Alberta, Saskatchewan, and Manitoba permit triples, and only the western provinces permit Rockies.

- Vehicle length limits vary by LCV configuration. Where permitted, Rockies are limited to lengths ranging from 31.0 to $41.0 \mathrm{~m}$, turnpikes are limited to lengths of either 40.0 or $41.0 \mathrm{~m}$ (Québec specifies the maximum trailer length but does not specify a vehicle length limit for turnpikes), and triples are limited to lengths ranging from 35.0 to $41.0 \mathrm{~m}$.

- Gross vehicle weight (GVW) limits also vary by LCV configuration. For Rockies, the GVW limit is $63,500 \mathrm{~kg}$ if the vehicle utilizes a B coupling device; this limit is lower if the vehicle's trailers are connected using an A $(53,500 \mathrm{~kg})$ or C $(60,500 \mathrm{~kg})$ coupling device. For turnpikes, GVW limits range between 62,500 kg (in Nova Scotia) and 67,500 kg (in Québec), and depend on the number of axles in the configuration. Triples have a GVW limit of 53,500 kg. 
- The type of coupling device used between trailers in an LCV configuration influences the dynamic performance of the vehicle. Generally, vehicles equipped with B or C coupling devices have superior stability and are more easily operated in reverse compared to vehicles equipped with A coupling devices; however, they are less maneuverable around corners. Most jurisdictions do not specify the type of coupling device used in an LCV configuration. Exceptions include the prohibition of A coupling devices on triples in Saskatchewan and C coupling devices on turnpikes in Ontario, New Brunswick, and Nova Scotia.

Additional, more detailed regulations related to truck size and weight also exist. Such details involve the relative weights of trailers and/or axles within the configuration and trailer length restrictions.

\section{Equipment Requirements}

Table 5 summarizes equipment requirements for LCVs in Canada; these requirements influence vehicle maneuverability, visibility, and dynamic performance. Principal observations about these requirements follow:

- Most jurisdictions control vehicle maneuverability by specifying power requirements for tractors towing LCV configurations (either in terms of a weight-to-power ratio or minimum engine horsepower) and by mandating certain braking equipment (e.g., anti-lock braking systems, relay valves, air reservoirs, compressors, air dryers).

- Except for Alberta, Saskatchewan, and the Northwest Territories, all jurisdictions stipulate visibility aids to improve LCV conspicuity. A variety of visibility aids are specified, including lateral lights for long trailers and rear-mounted signs identifying the vehicle as an LCV. addresses aspects of the dynamic performance of LCVs. 


\section{Operating Conditions}

LCVs in Canada must comply with a range of conditions which dictate how and when they operate. Table 6 summarizes these conditions; principal observations follow:

- All jurisdictions except the Northwest Territories restrict the maximum operating speed of LCVs at either 90 or $100 \mathrm{~km} / \mathrm{h}$. Depending on the route and posted speed limit, these restrictions may introduce an operating speed differential between LCVs and other traffic.

- In five jurisdictions, LCVs are required to operate in the right-hand lane of a multi-lane highway except: a) when conditions are impractical to do so (as in Ontario); b) when passing (as in British Columbia and Manitoba); or c) in case of emergency (as in New Brunswick and Nova Scotia). Alberta, Saskatchewan, Québec, and the Northwest Territories do not specify lane restrictions for LCVs.

- British Columbia, Ontario, Québec, New Brunswick, and Nova Scotia require LCVs to adhere to a minimum spacing within the traffic stream. This minimum spacing ranges from $150 \mathrm{~m}$ in Ontario and Québec to $1000 \mathrm{~m}$ in British Columbia, but varies depending on the types of vehicles considered. No such requirements are specified by Alberta, Saskatchewan, Manitoba, and the Northwest Territories.

- Except for Alberta, all jurisdictions prohibit LCVs from hauling certain types of cargo. Cargo restrictions include unstable bulk loads, hanging loads, livestock, dangerous goods, and unsecured loads.

- Except in the Northwest Territories, all jurisdictions prohibit LCV operations during adverse weather conditions. Although the definition of these conditions differs, they are typically defined in terms of visibility, traction, and the presence of cross wind.

- Most jurisdictions (except Québec and the Northwest Territories) stipulate safe refuge locations for LCVs in case they encounter adverse weather or experience an emergency. New Brunswick 
and Nova Scotia indicate that LCVs must activate 4-way flashing lights if travelling at or below 70 $\mathrm{km} / \mathrm{h}$ on the arterial highway network. restrictions designed to limit or prohibit LCV operations during peak traffic conditions. Despite numerous differences in the details of these restrictions across the country, three general types of temporal restrictions are evident:

1. Business: These restrictions primarily prohibit LCV operations during daytime weekday hours. In some cases, these restrictions are limited to short morning and afternoon timeframes during peak commuting hours. In other cases, these restrictions extend from the morning to the afternoon hours and occasionally into the late afternoon.

Fig. 3 and Fig. 4 identify routes subject to temporal restrictions and the type of restriction for western and eastern Canada, respectively. The maps reveal that LCV operations are commonly

284 temporally restricted:

2. Recreational: These restrictions prohibit LCV operations during certain weekend hours or around statutory holidays. Weekend restrictions prohibit operations at the start, middle, and/or end hours of the weekend or extended weekend. For statutory holidays, restrictions prohibit operations on the statutory holiday itself and sometimes on the day or latter portions of the day preceding a statutory holiday.

3. Hybrid: These restrictions prohibit LCV operations at a range of times which fall within both the business and recreational designations.

- around weekend peak recreation hours or on holidays on rural highways and in or near urban areas (this is especially evident in eastern Canadian jurisdictions except Nova Scotia); 
- during peak weekday rush hour(s) in or near urban areas (primarily evident in Saskatchewan, Ontario, Québec, New Brunswick, and Nova Scotia); and

- on certain two-lane undivided highways.

\section{Driver Qualifications}

Drivers operating LCVs in Canada must comply with certain requirements before receiving their LCV driver's certificate. Table 7 summarizes LCV driver qualifications. Principal observations about these qualifications follow:

- In all jurisdictions, LCV drivers must hold a valid license for operating a commercial truck equipped with airbrakes.

- Beyond holding a valid commercial driver's license, LCV drivers in all jurisdictions must have a minimum level of experience and training prior to operating an LCV. Minimum experience levels-expressed in either years or distance driven-vary between jurisdictions. The western provinces require at least two years of experience driving articulated configurations whereas the eastern provinces require five years of experience. Moreover, all jurisdictions require drivers to complete an LCV driver training course.

- Except in Québec, LCV drivers must maintain a minimum level of performance. In most cases, drivers must not have more than two moving violations within a 12-month period and not more than three moving violations within a 36-month period.

\section{Implications for Geometric Design and Highway Operations}

The regulations governing LCV operations in Canada directly influence geometric design and highway operations by defining vehicle specifications and performance, controlling LCV operations spatially and temporally, and stipulating driver and carrier performance criteria. Perhaps less obviously, 
the extent of network connectivity enabled by the regulations and the degree to which they provide

310 inter-jurisdictional uniformity also affect the quantity of LCV activity. As LCV activity increases, these

311 vehicles become a more prominent factor in the design and operation of highways. This section

312 describes details of these effects.

\section{Vehicle Specifications and Operating Performance}

Size and weight limits are a primary feature of LCV regulations across Canada. Despite some

variability in the details of these limits for LCVs in Canada, from a geometric design perspective, the principal consideration is the extended length at which these vehicles operate relative to other truck configurations. In most jurisdictions, the GVW and axle load limits are not higher than those governing other articulated truck configurations. Notably, the excess vehicle length has not been formally recognized in Canadian highway design guidance. According to the current version of the Geometric normally expected to operate within a limited jurisdiction" and are "normally of local interest".

322 Adjustments to design vehicle specifications were not within the scope of the forthcoming update to

323 this Guide. Despite this, highway designers in jurisdictions where LCV operations are commonplace have 324 recognized the need to adapt geometric features such as intersection turning radii, intersection sight 325 distances, and lane widths to better accommodate the performance characteristics of LCVs (Barton and 326 Morrall 1998; Kenny, Kwan, and Morrall 2002; Harwood et al. 2003; Woodrooffe and Milliken 2007; 327 Billing and Madill 2010; Maranchuk and Regehr 2015). LCV regulations also define aspects of vehicle performance by establishing limits for dynamic

329 performance measures or prescribing equipment-related criteria known to influence dynamic 330 performance. Common dynamic performance measures for trucks include (Harwood et al. 2003, OECD 331 2011, FHWA 2015): turning radius, offtracking and swept path width, trailer swingout, braking distance, 332 driver eye height, acceleration characteristics, speed-maintenance capabilities on grades, rearward 
amplification (i.e., trailer sway), suspension characteristics, load transfer ratio, and rollover threshold.

334 Based on the synthesis of regulations in the previous section, of these performance measures, only trailer sway is explicitly limited within Canadian LCV permits. Other performance measures are controlled indirectly. Table 8 lists aspects of LCV operating performance stipulated by Canadian regulations, the dynamic performance measures that these regulations primarily influence, and illustrative interdependencies between these measures and geometric design elements.

\section{Spatial and Temporal Controls}

Spatial and temporal controls are common elements of LCV permits across Canada. All Canadian

jurisdictions impose spatial controls by designating the highway network on which LCVs can operate as part of the permit. Normally, the criteria used to define such networks include cross-sectional features

(e.g., divided or undivided, number of lanes, paved shoulder width on two-lane undivided roads) and the potential magnitude of demand for LCV travel on a network link. Thus, the LCV regulations help define and control the vehicles that should be accommodated in the design of a highway and how it is operated and managed. Experience in some jurisdictions also provides evidence that design-related changes sometimes cause changes in the LCV network-seemingly inadvertently. For example, in the Canadian Prairie Provinces, LCV permits allow turnpike doubles and triples to operate on divided highways. In the last decade, each of these provinces have invested in highway twinning projects, presumably for the purposes of improving traffic operations or safety, but likely not with the direct intent of expanding the LCV network. Nevertheless, as twinning projects were completed, jurisdictions modified their LCV networks to reflect the new infrastructure conditions. Principal examples of these effects occurred along the Trans Canada Highway in Manitoba and Saskatchewan, along the Yellowhead Highway in Saskatchewan, and along Highway 43 between Edmonton and Grande Prairie, Alberta. 
urban areas. These regulations limit the potentially adverse operational interactions that may occur

358 when LCVs operate within the traffic stream. Weather-related restrictions are less predictable, but are

359 similarly aimed at limiting (or prohibiting) LCV operations during adverse road or weather conditions.

360 The diverse application of temporal restrictions (see Fig. 3 and Fig. 4) and the inconsistent definitions

361 used to specify weather-related restrictions pose challenges for scheduling and dispatching long-

362 distance trips through multiple jurisdictions. Montufar and Clayton (2002) recognize these challenges in

363 the application of seasonal truck weight limits, and emphasize opportunities for regional regulatory

364 rationalization and harmonization. Opportunities applicable to the context of LCV operations include

365 (Montufar and Clayton 2002):

366

- simplifying regulations to eliminate minor variances between jurisdictions if there is no scientific basis for the variances;

- considering harmonization opportunities across regions or along multi-jurisdictional corridors; and

- leveraging technologies to support better communication of regulations, potentially as part of the permitting process.

\section{LCV Driver and Carrier Performance}

LCV regulations specify strict driver qualifications as a prerequisite for the operation of LCVs,

374 including licensing requirements and minimum levels of training and experience. Moreover, all

375 jurisdictions consider carrier safety performance prior to granting LCV operating permits. A driver's

376 history of involvement in crashes and driving violations is known to be a strong predictor of future crash

377 involvement (Knipling 2009, OECD 2011). Indeed, Woodrooffe (2001) identified driver qualification

378 requirements as one of the permit conditions "found to be a vital influencing factor in the creation of a

379 safe [LCV] operating environment in Alberta". There is also evidence that the safety culture of a carrier

380 influences the safety performance of the driver (Knipling 2009). 
From a highway engineering perspective, the expectation that LCVs are being operated by highly

qualified drivers offsets the potentially difficult operational maneuvers that these vehicles encounter.

383 Thus, maintaining stringent driver and carrier qualifications appears prudent. However, current driver

shortages in the trucking industry and the potential for increased demand for LCV operations to deplete the pool of qualified drivers may challenge the sustainability of this expectation in the future.

\section{Network Connectivity and Inter-Jurisdictional Regulatory Harmonization}

Physical changes to certain roadway design features-such as twinning a previously undivided highway or widening the paved shoulder width-define whether LCV travel may occur on that link and impact the system-wide extent of LCV activity if they contribute to regional network connectivity. The example of the ever-expanding network of divided highways in the Canadian Prairie Provinces is again appropriate to consider. Ten years ago, the LCV network in Alberta, Saskatchewan, and Manitoba was incomplete from the perspective of facilitating regional LCV travel between major origin-destination pairs. That is, while it enabled intra-jurisdictional movements (e.g., between Calgary and Edmonton, Alberta; between Regina and Saskatoon, Saskatchewan; between Winnipeg and Brandon, Manitoba), gaps in the network precluded significant levels of inter-jurisdictional LCV movement. As these gaps were closed, however, available evidence shows a corresponding increase in the levels of LCV activity in the region (Regehr 2009; Regehr, Montufar, and Clayton 2009a; Regehr et al. 2009b; Di Cristoforo et al. 2012).

In addition to network connectivity, LCV travel may also be influenced by the degree of regulatory harmonization. A lack of uniformity of regulations between jurisdictions can render a physically connected network ineffective if compliance with disparate cross-jurisdictional regulations becomes too onerous for a carrier. Public agencies have demonstrated recognition of the benefits of harmonizing LCV regulations and have made progress in achieving this goal. Principal examples are the 
recent signing of the Turnpike double MoU among western Canadian provinces and the subsequent

405 signing of the Turnpike double MoU among eastern Canadian provinces.

From a highway engineering perspective, awareness of the status of these efforts may help

407 define future LCV volumes on specific network links. As LCVs become more prominent within the traffic

408 stream, there is a need to explicitly consider their performance characteristics when designing geometry

409 and managing operations.

\section{Concluding Remarks}

LCVs have been operating in Canada for decades, but with nine provinces/territories now

412 permitting LCV operations in some form, these operations have never been so widespread or extensive.

413 Based on evidence from across Canada compiled for the first time in this article, LCVs currently operate

414 on a network of approximately $17,000 \mathrm{~km}$. This network comprises fully interconnected regional

415 systems throughout the Prairie Provinces and the Northwest Territories, between Ontario and Québec,

416 and between New Brunswick and Nova Scotia. Forthcoming highway upgrades are expected to provide

417 operational connectivity for LCVs from Windsor, Ontario through to Halifax, Nova Scotia. A fully national

418 system would entail substantial efforts to close existing gaps between selected routes in British

419 Columbia and the network in the prairies, and between the prairies and the eastern Canadian network.

420 Canadian LCV regulations govern how carriers obtain operating permits, truck size and weight

421 limits, equipment requirements, operating conditions, and driver qualifications. The national-level

422 synthesis of regulations presented in this article reveals many similarities - particularly at the regional

423 scale-owing principally to recent regional agreements aimed at improving regulatory uniformity.

424 Achieving such uniformity is neither straightforward nor inevitable, but rather the outcome of ongoing

425 collaborative efforts among jurisdictions and between government and private industry. Despite these

426 general commonalities, opportunities remain to work towards increased regulatory harmonization 
427 across the country. From the highway geometric design and operations perspectives, improved

428 regulatory harmonization provides the impetus and opportunity to consider LCVs and their unique 429 operational characteristics more formally.

The following points summarize key findings from the regulatory review and the implications of these regulations for geometric design and highway operations:

432 - In all jurisdictions, only certified LCV carriers may operate LCVs. This, coupled with enhanced geometric or operational conditions.

- Turnpikes are the only LCV configuration permitted in all jurisdictions; Rockies and triples are not permitted in the eastern Canadian provinces. The size and weight limits applicable to these configurations exhibit some variation between jurisdictions. When explicitly stipulated in the permit, equipment requirements exhibit only minor variations between jurisdictions; the more apparent difference here is the lack of specification of certain equipment requirements by some jurisdictions. The regulations governing vehicle dimensions, weights, and equipment influence a vehicle's dynamic performance and consequently affect the design of various geometric elements.

- Operating conditions define and control where and when LCVs operate and consequently the circumstances in which design and operational decisions should account for their unique characteristics. These operating conditions exhibit variability between jurisdictions and present opportunities for improved regulatory harmonization.

- The network connectivity afforded by LCV regulations and the inter-jurisdictional harmonization of LCV regulations indirectly influence the magnitude of LCV activity. As LCV activity increases, 

becomes more apparent.

452

454 balance the often-competing objectives of productivity, energy efficiency, infrastructure preservation, 455 and safety. The regulations set out in provincial/territorial permits help to achieve this balance by 456 transparently subjecting more productive vehicles to more stringent operating requirements.

\section{Acknowledgements}

The authors thank the public-sector representatives who helped clarify various aspects of the

459 regulations described in this article. The financial support of the Natural Sciences and Engineering

460 Research Council (NSERC) of Canada is gratefully acknowledged. 


\section{References}

463 Barton, R. and J. Morrall. 1998. Study of long combination vehicles on two-lane highways. Transportation Research Record: Journal of the Transportation Research Board, 1613: 43-49.

Billing, J. R., and Madill, R. B. 2010. Introduction of long combination vehicles in Ontario. In Proceedings of the $11^{\text {th }}$ International Symposium on Heavy Vehicle Weights \& Dimensions, Melbourne, Australia.

Burns, N. 1983. The operation of overlength vehicles - the Saskatchewan experience. SAE Technical Papers, no. 831164.

Communications New Brunswick. 2005. Long combination vehicle pilot project on New Brunswick highways. Available from http://www.gnb.ca/cnb/news/tran/2005e0207tr.htm [cited 9 June 2017].

Di Cristoforo, R., Regehr, J.D., Germanchev, A., and Rempel, G. 2012. Survival of the fittest: using evolution theory to examine the impact of regulation on innovation in Australian and Canadian trucking. Heavy Vehicle Transport Technology 12, Stockholm, Sweden.

Federal Highway Administration. 2015. Highway safety and truck crash comparative analysis technical report: comprehensive truck size and weight limits study. U.S. Department of Transportation, Washington D.C.

Girling, R.R. 1988. Overweight/overdimension trucking in Manitoba and western Canada. Master's of Science Thesis, Department of Civil Engineering, University of Manitoba.

Harwood, D.W., Torbic, D.J., Richard, K.R., Glauz, W.D., and Elefteriadou, L. 2003. Review of truck characteristics as factors in roadway design. National Cooperative Highway Research Program Report 505, Transportation Research Board, Washington, D.C. 
484 485 486 487 488 489 490 491 492 493 494 495 496

Kenny, B., Kwan, A., and Morrall, J. 2002. Design and operational considerations to accommodate long combination vehicles and log haul trucks on rural highways in Alberta, Canada. In Proceedings of the $7^{\text {th }}$ International Symposium on Heavy Vehicle Weights \& Dimensions, Delft, The Netherlands.

Knipling, R.R. 2009. Safety for the long haul. The American Trucking Associations, Inc., Arlington, VA. Maranchuk, K. and Regehr, J.D. 2015. Highway and rail network planning and design for inland ports. In Proceedings of the Annual Conference of the Transportation Association of Canada, Charlottetown, PEI.

McCormick, C. 2009. LCVs: The eastern Canada experience. Available from http://www.trucknews.com/features/lcvs-the-eastern-canada-experience/ [cited 1 November 2016].

Montufar, J. and Clayton, A. 2002. Seasonal weight limits on prairie region highways: opportunities for rationalization and harmonization. Canadian Journal of Civil Engineering, 29: 8-16.

Nix, F.P. 1995. Long truck activity in Canada. Canadian Trucking Research Institute, Ottawa, ON.

Ontario Ministry of Transportation. 2016. Long combination vehicle (LCV) program - frequently asked Questions. Available from http://www.mto.gov.on.ca/english/trucks/long-combination-vehiclesfaq.shtml [cited on 1 November 2016].

Organisation for Economic Cooperation and Development (OECD). 2011. Moving freight with better trucks: improving safety, productivity and sustainability. OECD Publishing.

Québec Portal. 2015. Canada and Québec to support completion of construction of Highway 85. Available from http://www.filinformation.gouv.qc.ca/Pages/Article.aspx?aiguillage=ajd\&type=1\&lang=en\&idArticle=2307137 $\underline{665}$ [cited 9 June 2017]. 
507 Ray Barton Associates Ltd. and L. P. Tardif and Associates Ltd. 2003. Literature review of the safety of 508 long combination vehicles and their operation in Canada. Canada Safety Council, Ottawa, ON.

509

510

Regehr, J.D. 2009. Exposure modelling of productivity-permitted general freight trucking on uncongested highways. Doctor of Philosophy Thesis, Department of Civil Engineering, University of Manitoba.

Regehr, J.D., Montufar, J., and Clayton, A. 2009a. Lessons learned about the impacts of size and weight regulations on the articulated truck fleet in the Canadian prairie region. Canadian Journal of Civil Engineering, 36(4): 607-616.

Regehr, J.D., Montufar, J., and Rempel, G. 2009b. Safety performance of longer combination vehicles relative to other articulated trucks. Canadian Journal of Civil Engineering, 36(1): 40-49.

Transport Canada. 2011. National Highway System. Available from https://www.tc.gc.ca/eng/policy/acgacgd-menu-highways-2149.htm [cited 9 June 2017].

Truck News. 2008. B.C. considers approving Rocky Mountain doubles on provincial highways. Available from http://www.trucknews.com/regulations/b-c-considers-approving-rocky-mountaindoubles-on-provincial-highways/1000078209/ [cited 1 November 2016].

Truck News. 2011. EXCLUSIVE: Ontario LCV program a "pilot" no more. Available from http://www.trucknews.com/regulations/exclusive-ontario-lcv-program-a-pilot-nomore/1000403160/ [cited 1 November 2016].

Woodrooffe, J. 2001. Long combination vehicle (LCV) safety performance in Alberta 1995 to 1998. Woodrooffe \& Associates.

Woodrooffe, J. and Milliken, P. 2007. Safety analysis of a double \& triple b-train carrying loaded containers. Woodrooffe \& Associates. 
529 Woodrooffe, J., Sweatman, P., Middleton, D., James, R., and Billing, J.R. 2010. Review of Canadian experience with the regulation of large commercial motor vehicles. National Cooperative Highway Research Program Report 671, Transportation Research Board, Washington, D.C. 


\section{Tables}

533 Table 1. Three common LCV configurations in Canada.

\begin{tabular}{lll}
\hline LCV configuration & Diagram of a typically-configured LCV & Axle configuration \\
\hline Turnpike double & $\begin{array}{l}\text { 3-S2-3, 3-S2-4 (shown), 3- } \\
\text { S2-5, others } \\
3-S 2-2 \text { (shown), others }\end{array}$ & $\begin{array}{l}\text { 2-S1-2-2 (shown), 3-S1-2- } \\
\text { 2, others }\end{array}$ \\
Rocky Mountain double trailer combination &
\end{tabular}

534 
Table 2. Kilometres of LCV highway network in Canadian jurisdictions, $1970-2016^{a}$.

\begin{tabular}{lllllll}
\hline Jurisdiction & c. 1970 & c. 1982 & c. 1988 & c. 1995 & 2007 & 2016 \\
\hline British Columbia & 0 & 0 & 0 & 0 & 0 & 700 \\
\hline Alberta & 300 & 1300 & 2400 & 3900 & 5300 & 6100 \\
\hline Saskatchewan & 0 & 500 & 3100 & 3600 & 4100 & 4200 \\
\hline Manitoba & 0 & 300 & 400 & 700 & 1600 & 900 \\
\hline Ontario & 0 & 0 & 0 & 0 & 0 & 1600 \\
\hline Québec & 0 & 0 & $1800^{b}$ & $1800^{b}$ & $1800^{b}$ & 1800 \\
\hline New Brunswick & 0 & 0 & 0 & 0 & $200^{c}$ & 800 \\
\hline Nova Scotia & 0 & 0 & 0 & 0 & 0 & 300 \\
\hline Northwest & 0 & 0 & 300 & 300 & $600^{d}$ & 600 \\
Territories & & & & & & 13,600 \\
\hline Total & 300 & 2100 & 6200 & 10,300 & 17,000 \\
\hline
\end{tabular}

$536{ }^{a}$ The historical statistics presented in the table are compiled from available evidence provided by Burns 1983;

537 Girling 1988; Nix 1995; Communications New Brunswick 2005; and Regehr 2009. The authors consider the values

538 presented to be estimates, as it is difficult to independently validate the data. Statistics for 2016 are based on

539 original analysis by the authors.

$540{ }^{b}$ For the purpose of this research, the distances reported for Québec in 1988, 1995, and 2007 are assumed to

541 equal the 2016 distance. This distance generally agrees with the estimate provided by Nix (1995).

$542{ }^{c}$ Communications New Brunswick (2005) indicates that the original one-year pilot project for LCV operations in

543 New Brunswick commenced in February 2005. It is unclear whether this network had been extended by 2007.

$544{ }^{d}$ For the purpose of this research, the distance reported for the Northwest Territories in 2007 is assumed to equal

545 the 2016 distance. 
546 Table 3. Permit requirements for LCV carriers in Canada, 2016.

\begin{tabular}{|c|c|c|c|}
\hline Jurisdiction & Permit required? & Term length & How to maintain permits \\
\hline $\begin{array}{l}\text { British } \\
\text { Columbia }\end{array}$ & Yes & N/A & $\begin{array}{l}\text { Abide by permit conditions and } \\
\text { maintain safety rating of "Satisfactory" }\end{array}$ \\
\hline Alberta & Yes & $\begin{array}{l}\text { Maximum } 12 \\
\text { months }\end{array}$ & $\begin{array}{l}\text { Abide by permit conditions and Traffic } \\
\text { Safety Act }\end{array}$ \\
\hline Saskatchewan & Yes & 12 months & Abide by permit conditions \\
\hline Manitoba & Yes & $\begin{array}{l}\text { Maximum } 12 \\
\text { months }\end{array}$ & Abide by permit conditions \\
\hline Ontario & Yes $^{a}$ & 12 months & $\begin{array}{l}\text { Abide by permit conditions and } \\
\text { maintain safety rating of "Satisfactory" }\end{array}$ \\
\hline Québec & Yes & 3 to 9 months & Abide by permit conditions \\
\hline New Brunswick & Yes & 12 months & $\begin{array}{l}\text { Abide by permit conditions and } \\
\text { maintain safety rating of "Satisfactory" }\end{array}$ \\
\hline Nova Scotia & Yes & 12 months & $\begin{array}{l}\text { Abide by permit conditions and safety } \\
\text { requirements }\end{array}$ \\
\hline $\begin{array}{l}\text { Northwest } \\
\text { Territories }\end{array}$ & Yes & 12 months & $\begin{array}{l}\text { Abide by permit conditions and safety } \\
\text { requirements }\end{array}$ \\
\hline
\end{tabular}

548 carrier. 
Table 4. Truck size and weight limits governing LCV operations in Canada, 2016.

\begin{tabular}{|c|c|c|c|c|}
\hline Jurisdiction & $\begin{array}{l}\text { LCV } \\
\text { configuration }\end{array}$ & Vehicle length limit (m) & $\begin{array}{l}\text { Gross vehicle } \\
\text { weight limit (kg) }\end{array}$ & $\begin{array}{l}\text { Coupling device } \\
\text { between trailers }\end{array}$ \\
\hline \multirow{2}{*}{$\begin{array}{l}\text { British } \\
\text { Columbia }\end{array}$} & Rocky & $31.0-32.0^{b}$ & $63,500^{c, d}$ & $A, B, C$ \\
\hline & Turnpike & 41.0 & $63,500^{d}$ & $A, B, C$ \\
\hline \multirow[t]{3}{*}{ Alberta } & Rocky & 31.0 & $63,500^{c}$ & $A, B, C$ \\
\hline & Turnpike & 41.0 & $63,500^{d}$ & $A, B, C$ \\
\hline & Triple & $38.0^{e}$ & 53,500 & $A, B, C$ \\
\hline \multirow[t]{3}{*}{ Saskatchewan } & Rocky & 31.0 or $41.0^{f}$ & $63,500^{c}$ & $A, B, C$ \\
\hline & Turnpike & 41.0 & 63,500 & $A, B, C$ \\
\hline & Triple & 41.0 & 53,500 & $\mathrm{~B}, \mathrm{C}$ \\
\hline \multirow[t]{3}{*}{ Manitoba } & Rocky & 32.5 or $41.0^{f}$ & $63,500^{c}$ & $A, B, C$ \\
\hline & Turnpike & 41.0 & 63,500 & $A, B, C$ \\
\hline & Triple & 35.0 & 53,500 & $A, B, C$ \\
\hline Ontario & Turnpike & 40.0 & 63,500 & $A, B$ \\
\hline Québec & Turnpike & Trailers limited to 16.2 & 67,500 & $A, B, C$ \\
\hline New Brunswick & Turnpike & 40.0 & $63,500^{d}$ & $A, B$ \\
\hline Nova Scotia & Turnpike & 40.0 & $62,500^{d}$ & $A, B$ \\
\hline $\begin{array}{l}\text { Northwest } \\
\text { Territories }\end{array}$ & Rocky & 31.0 & $63,500^{c, d}$ & $A, B, C$ \\
\hline
\end{tabular}

${ }^{a}$ Three main coupling devices are used to connect trailers within an LCV configuration. An A coupling device

551 contains a pintle hook attached to single or tandem axle group and a fifth-wheel. This device contains two

552 articulation points: one at the fifth-wheel and one at the pintle hook on the rear of the lead trailer. It does not

553 transfer roll between vehicle units. A B coupling device contains a tandem or tridem axle group rigidly fixed to the

554 lead trailer and a fifth wheel. This device contains one articulation point at the fifth-wheel and transfers roll

555 between the vehicle units. A C coupling device contains double draw bars attached to a single or tandem axle

556 group and a fifth-wheel. This device contains one articulation point at the fifth-wheel and transfers roll between

557 vehicle units.

$558{ }^{b}$ depending on route

$559{ }^{c}$ only for B coupled vehicles

$560{ }^{d}$ only for vehicles with eight or more axles

$561 e^{e}$ only for double B coupled vehicles

$562{ }^{f}$ lower limit applies to two-lane highways; upper limit applies to four-lane highways 
563 Table 5. Equipment requirements for LCV configurations in Canada, 2016.

\begin{tabular}{|c|c|c|c|c|c|c|}
\hline Jurisdiction & $\begin{array}{l}\text { Weight to } \\
\text { power } \\
\text { ratio } \\
(\mathrm{kg} / \mathrm{hp})\end{array}$ & $\begin{array}{l}\text { Brake } \\
\text { requirements }\end{array}$ & Pneumatics & $\begin{array}{l}\text { Special visibility } \\
\text { aids }\end{array}$ & $\begin{array}{l}\text { A and C } \\
\text { coupling } \\
\text { devices }\end{array}$ & $\begin{array}{l}\text { Maximum } \\
\text { lateral } \\
\text { trailer } \\
\text { sway }(\mathrm{cm})\end{array}$ \\
\hline $\begin{array}{l}\text { British } \\
\text { Columbia }\end{array}$ & 150 & $\begin{array}{l}\text { Anti-lock } \\
\text { braking } \\
\text { system } \\
\text { (tractor only) }\end{array}$ & N/A & $\begin{array}{l}\text { Lateral lights } \\
\text { (for trailers > } \\
8.6 \mathrm{~m} \text { ) }\end{array}$ & $\begin{array}{l}\text { No slack } \\
\text { pintle } \\
\text { hooks }\end{array}$ & $\mathrm{N} / \mathrm{A}$ \\
\hline Alberta & 160 & Relay valves & $\begin{array}{l}\text { Air } \\
\text { reservoirs, } \\
\text { compressors }\end{array}$ & N/A & $\begin{array}{l}\text { No slack } \\
\text { pintle } \\
\text { hooks }\end{array}$ & 10 \\
\hline $\begin{array}{l}\text { Saskatche- } \\
\text { wan }\end{array}$ & 160 & Relay valves & $\begin{array}{l}\text { Air } \\
\text { reservoirs, } \\
\text { compressors }\end{array}$ & $\mathrm{N} / \mathrm{A}$ & $\begin{array}{l}\text { No slack } \\
\text { pintle } \\
\text { hooks }\end{array}$ & 10 \\
\hline Manitoba & 160 & Relay valves & $\begin{array}{l}\text { Air } \\
\text { reservoirs, } \\
\text { compressors }\end{array}$ & $\begin{array}{l}\text { "LONG LOAD" } \\
\text { sign. }{ }^{a}\end{array}$ & $\begin{array}{l}\text { No slack } \\
\text { pintle } \\
\text { hooks }\end{array}$ & 10 \\
\hline Ontario & $\begin{array}{l}425 \mathrm{hp} \\
\text { minimum }\end{array}$ & $\begin{array}{l}\text { Anti-lock } \\
\text { braking } \\
\text { system, relay } \\
\text { valves }\end{array}$ & $\begin{array}{l}\text { Air } \\
\text { compressor, } \\
\text { air dryers }\end{array}$ & $\begin{array}{l}\text { Side marker } \\
\text { lights, "LONG" } \\
\text { sign }\end{array}$ & $\begin{array}{l}\text { No slack } \\
\text { pintle } \\
\text { hooks }\end{array}$ & N/A \\
\hline Québec & 180 & Relay valves & $\begin{array}{l}\text { Air } \\
\text { compressor }\end{array}$ & "LONG" sign & N/A & 8 \\
\hline $\begin{array}{l}\text { New } \\
\text { Brunswick }\end{array}$ & $\begin{array}{l}460 \mathrm{hp} \\
\text { minimum }\end{array}$ & N/A & N/A & $\begin{array}{l}\text { LED lighting, } \\
\text { "LONG" sign }\end{array}$ & $\begin{array}{l}\text { No slack } \\
\text { pintle } \\
\text { hooks }\end{array}$ & N/A \\
\hline $\begin{array}{l}\text { Nova } \\
\text { Scotia }\end{array}$ & $\begin{array}{l}460 \text { hp } \\
\text { minimum }\end{array}$ & $\mathrm{N} / \mathrm{A}$ & N/A & $\begin{array}{l}\text { LED lighting, } \\
\text { "LONG" sign }\end{array}$ & $\begin{array}{l}\text { No slack } \\
\text { pintle } \\
\text { hooks }\end{array}$ & N/A \\
\hline $\begin{array}{l}\text { Northwest } \\
\text { Territories }\end{array}$ & $\mathrm{N} / \mathrm{A}$ & $\mathrm{N} / \mathrm{A}$ & N/A & $\mathrm{N} / \mathrm{A}$ & N/A & N/A \\
\hline
\end{tabular}


Table 6. Operating conditions for LCVs in Canada, 2016.

\begin{tabular}{|c|c|c|c|c|c|c|}
\hline Jurisdiction & $\begin{array}{l}\text { Maximu } \\
\text { m speed } \\
(\mathrm{km} / \mathrm{h})\end{array}$ & $\begin{array}{l}\text { Lane } \\
\text { restrictions }\end{array}$ & $\begin{array}{l}\text { Require } \\
\text { d } \\
\text { spacing } \\
\text { (m) }\end{array}$ & $\begin{array}{l}\text { Cargo } \\
\text { restriction } \\
\mathrm{S}\end{array}$ & $\begin{array}{l}\text { Restricted } \\
\text { weather } \\
\text { conditions }\end{array}$ & $\begin{array}{l}\text { Emergency } \\
\text { operations }\end{array}$ \\
\hline $\begin{array}{l}\text { British } \\
\text { Columbia }\end{array}$ & 100 & $\begin{array}{l}\text { Right hand } \\
\text { lane, except } \\
\text { when } \\
\text { passing; left } \\
\text { hand lane } \\
\text { prohibited } \\
\text { on six-lane } \\
\text { highways }\end{array}$ & $\begin{array}{l}1000^{b}, \\
500^{c}\end{array}$ & $\begin{array}{l}\text { Unstable } \\
\text { bulk loads, } \\
\text { hanging } \\
\text { loads, } \\
\text { dangerous } \\
\text { goods }\end{array}$ & $\begin{array}{l}\text { Adverse } \\
\text { weather, } \\
\text { visibility }<300 \\
\mathrm{~m} \text {, precipitation } \\
\text { affecting } \\
\text { traction }\end{array}$ & $\begin{array}{l}\text { Drivers must } \\
\text { stop at next } \\
\text { safe location }\end{array}$ \\
\hline Alberta & 100 & N/A & N/A & N/A & $\begin{array}{l}\text { Adverse } \\
\text { weather, } \\
\text { hazardous } \\
\text { precipitation/fo } \\
\mathrm{g}^{e}\end{array}$ & $\begin{array}{l}\text { Drivers must } \\
\text { stop at next } \\
\text { safe location }\end{array}$ \\
\hline $\begin{array}{l}\text { Saskatchewa } \\
\text { n }\end{array}$ & $90-100^{a}$ & $\mathrm{~N} / \mathrm{A}$ & $\mathrm{N} / \mathrm{A}$ & $\begin{array}{l}\text { Unstable } \\
\text { bulk loads, } \\
\text { hanging } \\
\text { loads, } \\
\text { livestock }\end{array}$ & $\begin{array}{l}\text { Adverse } \\
\text { weather, } \\
\text { hazardous } \\
\text { precipitation/fo } \\
\text { ge }\end{array}$ & $\begin{array}{l}\text { Drivers must } \\
\text { stop at next } \\
\text { safe location }\end{array}$ \\
\hline Manitoba & 100 & $\begin{array}{l}\text { Right hand } \\
\text { lane, except } \\
\text { when } \\
\text { passing }\end{array}$ & $\mathrm{N} / \mathrm{A}$ & $\begin{array}{l}\text { Unstable } \\
\text { bulk loads, } \\
\text { hanging } \\
\text { loads, } \\
\text { livestock }\end{array}$ & $\begin{array}{l}\text { Adverse } \\
\text { weather }\end{array}$ & $\begin{array}{l}\text { Drivers must } \\
\text { stop at next } \\
\text { safe location }\end{array}$ \\
\hline Ontario & 90 & $\begin{array}{l}\text { Right hand } \\
\text { lane when } \\
\text { practical }\end{array}$ & $150^{b}$ & $\begin{array}{l}\text { Dangerous } \\
\text { goods, } \\
\text { livestock }\end{array}$ & $\begin{array}{l}\text { Snow/ice on } \\
\text { road, visibility }< \\
500 \mathrm{~m}\end{array}$ & $\begin{array}{l}\text { Drivers must } \\
\text { proceed to the } \\
\text { nearest } \\
\text { rest/emergenc } \\
\text { y stop or safe } \\
\text { point off the } \\
\text { travelled } \\
\text { portion of the } \\
\text { highway }\end{array}$ \\
\hline Québec & 90 & N/A & $150^{d}$ & $\begin{array}{l}\text { Dangerous } \\
\text { goods }\end{array}$ & $\begin{array}{l}\text { Snow/ice on } \\
\text { road, visibility }< \\
500 \mathrm{~m}\end{array}$ & $\mathrm{~N} / \mathrm{A}$ \\
\hline $\begin{array}{l}\text { New } \\
\text { Brunswick }\end{array}$ & 90 & $\begin{array}{l}\text { Right hand } \\
\text { lane, except } \\
\text { for } \\
\text { emergencie } \\
\text { s }\end{array}$ & $300^{b}$ & $\begin{array}{l}\text { Dangerous } \\
\text { goods, } \\
\text { livestock }\end{array}$ & $\begin{array}{l}\text { Hazardous } \\
\text { precipitation/ } \\
\text { fog/cross wind, } \\
\text { snow/ice on } \\
\text { road, visibility < } \\
500 \text { m }\end{array}$ & $\begin{array}{l}\text { Driver must } \\
\text { exit the } \\
\text { highway at first } \\
\text { designated } \\
\text { refuge area; } \\
\text { activation of 4- }\end{array}$ \\
\hline
\end{tabular}




\begin{tabular}{|c|c|c|c|c|c|c|}
\hline & & & & & & $\begin{array}{l}\text { way flashing } \\
\text { lights required } \\
\text { at speeds } \leq 70 \\
\mathrm{~km} / \mathrm{h}\end{array}$ \\
\hline Nova Scotia & 90 & $\begin{array}{l}\text { Right hand } \\
\text { lane, except } \\
\text { for } \\
\text { emergencie } \\
\text { s }\end{array}$ & $500^{b}$ & $\begin{array}{l}\text { Dangerous } \\
\text { goods, } \\
\text { livestock }\end{array}$ & $\begin{array}{l}\text { Hazardous } \\
\text { precipitation/ } \\
\text { fog/cross wind, } \\
\text { snow/ice on } \\
\text { road, visibility < } \\
300 \text { m }\end{array}$ & $\begin{array}{l}\text { Driver must } \\
\text { exit the } \\
\text { highway at first } \\
\text { designated } \\
\text { refuge area; } \\
\text { activation of 4- } \\
\text { way flashing } \\
\text { lights required } \\
\text { at speeds } \leq 70 \\
\mathrm{~km} / \mathrm{h}\end{array}$ \\
\hline $\begin{array}{l}\text { Northwest } \\
\text { Territories }\end{array}$ & N/A & $\mathrm{N} / \mathrm{A}$ & $\mathrm{N} / \mathrm{A}$ & $\begin{array}{l}\text { Unsecured } \\
\text { loads }\end{array}$ & $\mathrm{N} / \mathrm{A}$ & N/A \\
\hline \multicolumn{6}{|c|}{${ }^{b}$ between two LCVs } & \\
\hline \multicolumn{7}{|c|}{${ }^{c}$ between LCV and commercial vehicles } \\
\hline \multicolumn{7}{|c|}{${ }^{d}$ between LCV and any vehicle } \\
\hline
\end{tabular}


571 Table 7. Qualifications for drivers operating LCVs in Canada, 2016.

\begin{tabular}{|c|c|c|c|c|}
\hline Jurisdiction & Required license & $\begin{array}{l}\text { Experience with } \\
\text { articulated } \\
\text { vehicles }\end{array}$ & Training & Moving violations \\
\hline $\begin{array}{l}\text { British } \\
\text { Columbia }\end{array}$ & Class 1 or equivalent & $\begin{array}{l}24 \text { months or } \\
150,000 \mathrm{~km}\end{array}$ & $\begin{array}{l}\text { Canadian Trucking } \\
\text { Alliance's (CTA) } \\
\text { LCV Course or } \\
\text { equivalent }\end{array}$ & $\begin{array}{l}\leq 2 \text { in past } 12 \text { months } \\
\text { and } \leq 3 \text { in past } 36 \\
\text { months }\end{array}$ \\
\hline Alberta & Class 1 or equivalent & $\begin{array}{l}24 \text { months or } \\
150,000 \mathrm{~km}\end{array}$ & $\begin{array}{l}\text { Alberta Motor } \\
\text { Transport } \\
\text { Association's LCV } \\
\text { Course or } \\
\text { equivalent }\end{array}$ & $\begin{array}{l}\leq 2 \text { in past } 12 \text { months } \\
\text { and } \leq 3 \text { in past } 36 \\
\text { months }\end{array}$ \\
\hline Saskatchewan & $\begin{array}{l}\text { Class } 1 \text { or equivalent } \\
\text { with airbrake } \\
\text { endorsement }\end{array}$ & $\begin{array}{l}24 \text { months or } \\
150,000 \mathrm{~km}\end{array}$ & $\begin{array}{l}\text { CTA's LCV Course } \\
\text { or equivalent }\end{array}$ & $\begin{array}{l}\leq 2 \text { in past } 12 \text { months } \\
\text { and } \leq 3 \text { in past } 36 \\
\text { months }\end{array}$ \\
\hline Manitoba & $\begin{array}{l}\text { Class } 1 \text { or equivalent } \\
\text { with airbrake } \\
\text { endorsement }\end{array}$ & $\begin{array}{l}24 \text { months or } \\
150,000 \mathrm{~km}\end{array}$ & CTA's LCV Course & $\begin{array}{l}\leq 2 \text { in past } 12 \text { months } \\
\text { and } \leq 3 \text { in past } 36 \\
\text { months }\end{array}$ \\
\hline Ontario & $\begin{array}{l}\text { Class A with airbrake } \\
\text { endorsement or } \\
\text { equivalent }\end{array}$ & 5 years & $\begin{array}{l}\text { Ontario Trucking } \\
\text { Association's LCV } \\
\text { Program or } \\
\text { equivalent }\end{array}$ & $\begin{array}{l}\leq 2 \text { in past } 12 \text { months } \\
\text { and } \leq 3 \text { in past } 36 \\
\text { months }\end{array}$ \\
\hline Québec & $\begin{array}{l}\text { Class } 1 \text { with "T" } \\
\text { certification }\end{array}$ & 5 years & $\begin{array}{l}\text { "T" certification or } \\
\text { equivalent }\end{array}$ & $\mathrm{N} / \mathrm{A}$ \\
\hline $\begin{array}{l}\text { New } \\
\text { Brunswick }\end{array}$ & $\begin{array}{l}\text { Class } 1 \text { with airbrake } \\
\text { endorsement }\end{array}$ & $\begin{array}{l}5 \text { years and } \\
150,000 \mathrm{~km}\end{array}$ & $\begin{array}{l}\text { Atlantic Provinces } \\
\text { Trucking } \\
\text { Association's LCV } \\
\text { Course or } \\
\text { equivalent }\end{array}$ & $\begin{array}{l}\leq 2 \text { in past } 12 \text { months } \\
\text { and } \leq 3 \text { in past } 36 \\
\text { months }\end{array}$ \\
\hline Nova Scotia & $\begin{array}{l}\text { Class } 1 \text { with airbrake } \\
\text { endorsement }\end{array}$ & $\begin{array}{l}5 \text { years and } \\
150,000 \mathrm{~km}\end{array}$ & $\begin{array}{l}\text { CTA's LCV Course } \\
\text { or equivalent }\end{array}$ & $\begin{array}{l}\leq 2 \text { in past } 12 \text { months } \\
\text { and } \leq 3 \text { in past } 36 \\
\text { months }\end{array}$ \\
\hline $\begin{array}{l}\text { Northwest } \\
\text { Territories }\end{array}$ & $\begin{array}{l}\text { Class } 1 \text { with airbrake } \\
\text { endorsement }\end{array}$ & 2 years & $\begin{array}{l}\text { LCV course or } \\
\text { verifiable } \\
\text { instruction from } \\
\text { employer }\end{array}$ & $\begin{array}{l}\leq 6 \text { demerit points in } \\
\text { past } 12 \text { months }\end{array}$ \\
\hline
\end{tabular}


573 Table 8. Regulations governing LCV operations and their relationship with dynamic performance 574 measures and geometric design elements.

\begin{tabular}{lll}
\hline Regulated item & $\begin{array}{l}\text { Examples of related dynamic } \\
\text { performance measure(s) }\end{array}$ & $\begin{array}{l}\text { Examples of related geometric design } \\
\text { elements }\end{array}$ \\
\hline Trailer sway & Trailer sway & $\begin{array}{l}\text { Lane width, pavement widening on } \\
\text { horizontal curves }\end{array}$ \\
\hline Coupling device & $\begin{array}{l}\text { Turning radius, offtracking and swept } \\
\text { path width, trailer sway, load transfer } \\
\text { ratio, rollover threshold }\end{array}$ & $\begin{array}{l}\text { Lane width, horizontal curve radius } \\
\text { and superelevation, pavement } \\
\text { widening on horizontal curves, }\end{array}$ \\
& & $\begin{array}{l}\text { intersection and channelization } \\
\text { geometrics }\end{array}$ \\
\hline Engine power & Acceleration, speed-maintenance on & $\begin{array}{l}\text { Critical length of grade, acceleration } \\
\text { lanes, intersection sight distance }\end{array}$ \\
\hline Braking systems & Brades & $\begin{array}{l}\text { Stopping sight distance, intersection } \\
\text { sight distance, deceleration lanes, }\end{array}$ \\
& & downgrades \\
\hline Maximum speeds & Offtracking and swept path width, & Sight distance, lane width \\
& braking distance, trailer sway & \\
\hline Lane restrictions & Acceleration & Passing sight distance \\
\hline Required spacing & Braking distance, acceleration & Sight distance \\
\hline Cargo restrictions & Load transfer ratio, rollover threshold & Horizontal curve radius \\
\hline Restricted & Braking distance, trailer sway & Sight distance, lane width \\
weather & & \\
conditions & & \\
\hline
\end{tabular}




\section{List of Figure Captions and Notes}

577 Fig. 1. LCV routes in western Canada, 2016.

578 Fig. 2. LCV routes in eastern Canada, 2016.

579 Fig. 3. Temporal restrictions on LCV routes in western Canada, $2016^{a}$.

$580{ }^{a}$ Three generalized types of LCV temporal restrictions are evident in Canadian jurisdictions: (1) business

581 restrictions, which typically prohibit operations during daytime hours on weekdays, (2) recreational restrictions,

582 which typically prohibit operations during certain hours on weekends or around statutory holidays, and (3) hybrid

583 restrictions, which represent a range of restrictions with both business and recreational components.

584 Fig. 4. Temporal restrictions on LCV routes in eastern Canada, $2016^{a}$.

$585{ }^{a}$ Three generalized types of LCV temporal restrictions are evident in Canadian jurisdictions: (1) business

586 restrictions, which typically prohibit operations during daytime hours on weekdays, (2) recreational restrictions,

587 which typically prohibit operations during certain hours on weekends or around statutory holidays, and (3) hybrid

588 restrictions, which represent a range of restrictions with both business and recreational components. 


\section{Page 35 of 38}

Canadian Journal of Civil Engineering

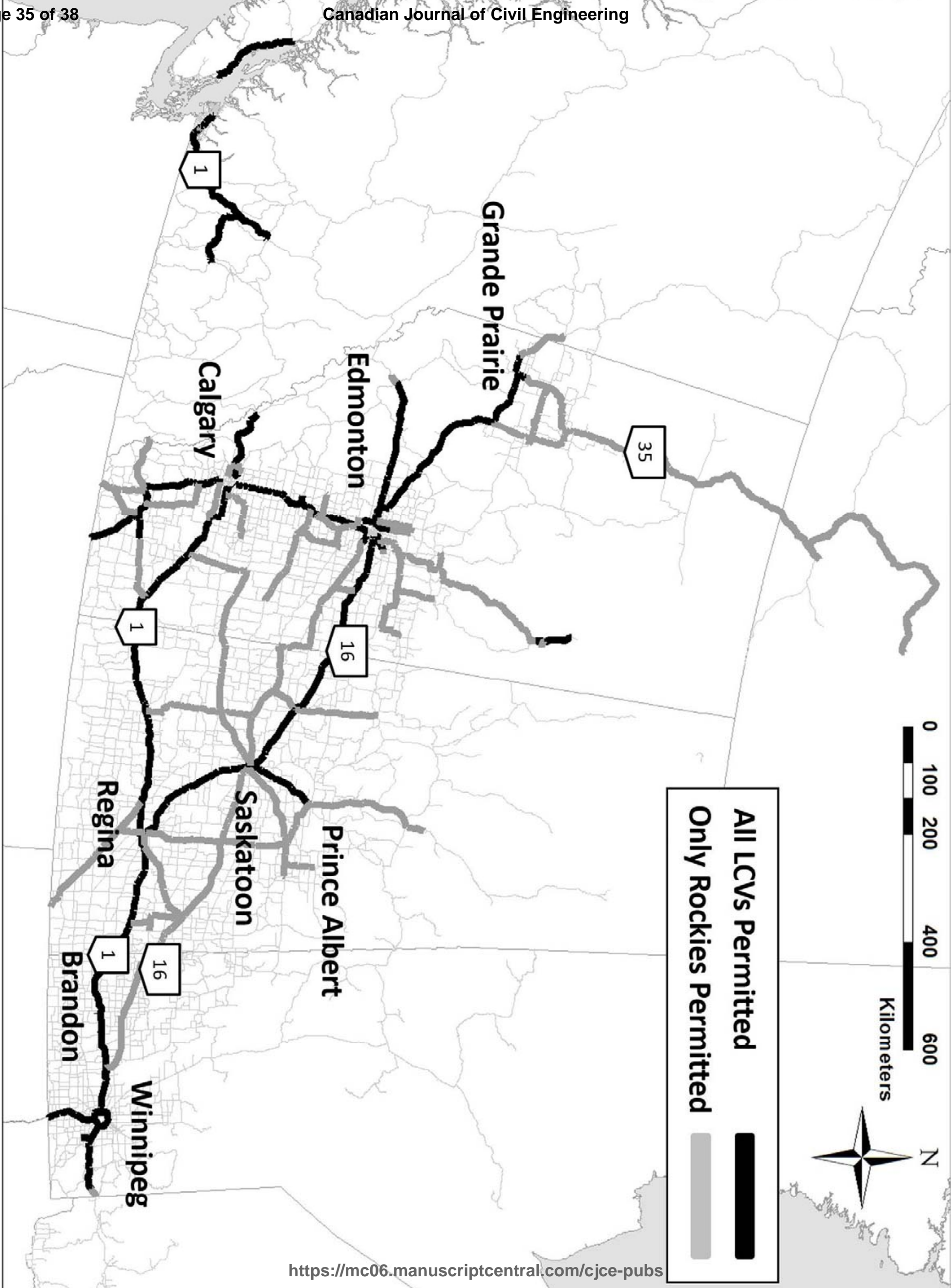




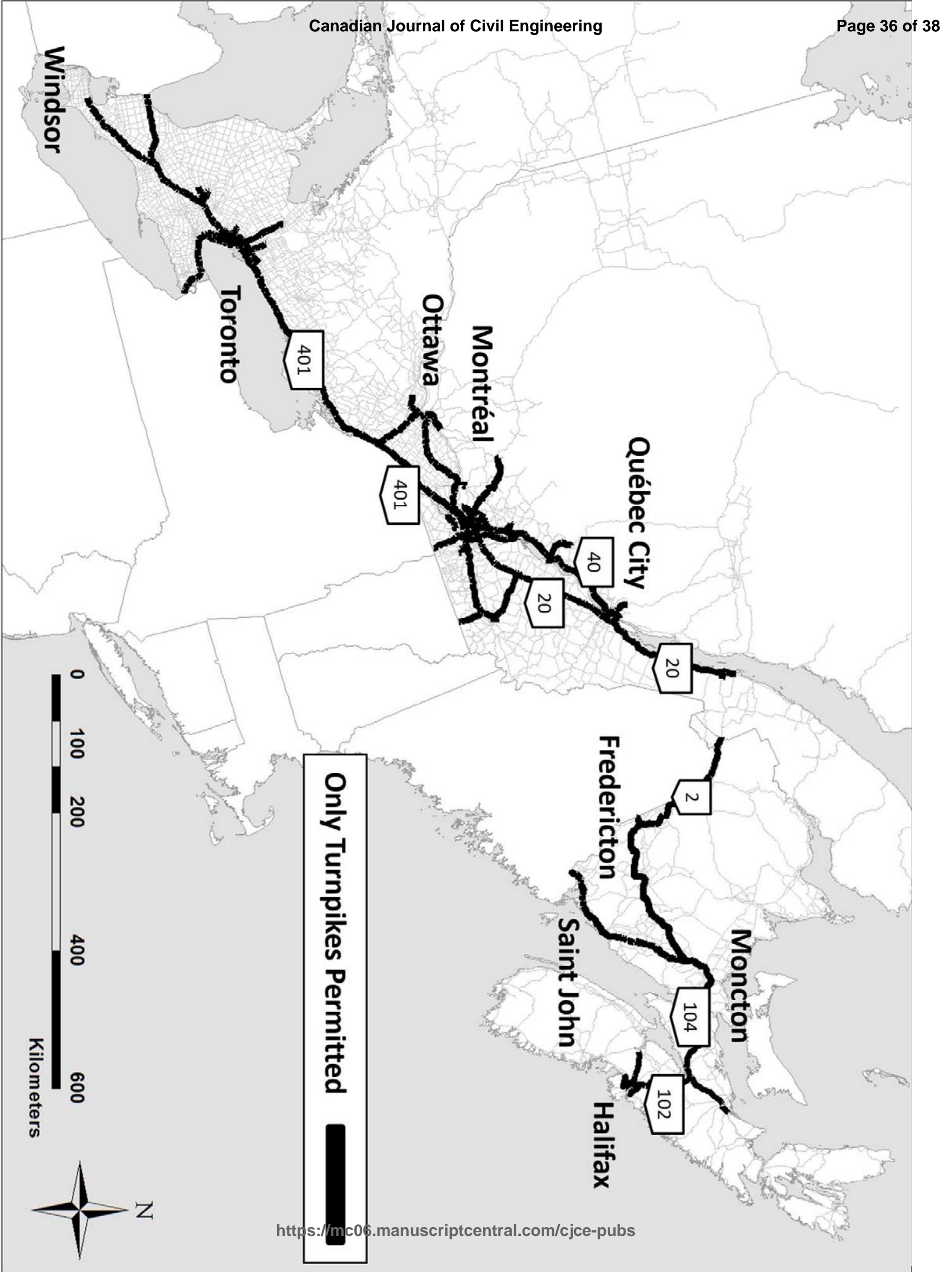




\section{Page 37 of 38 \\ Canadian Journal of Civit Engineering

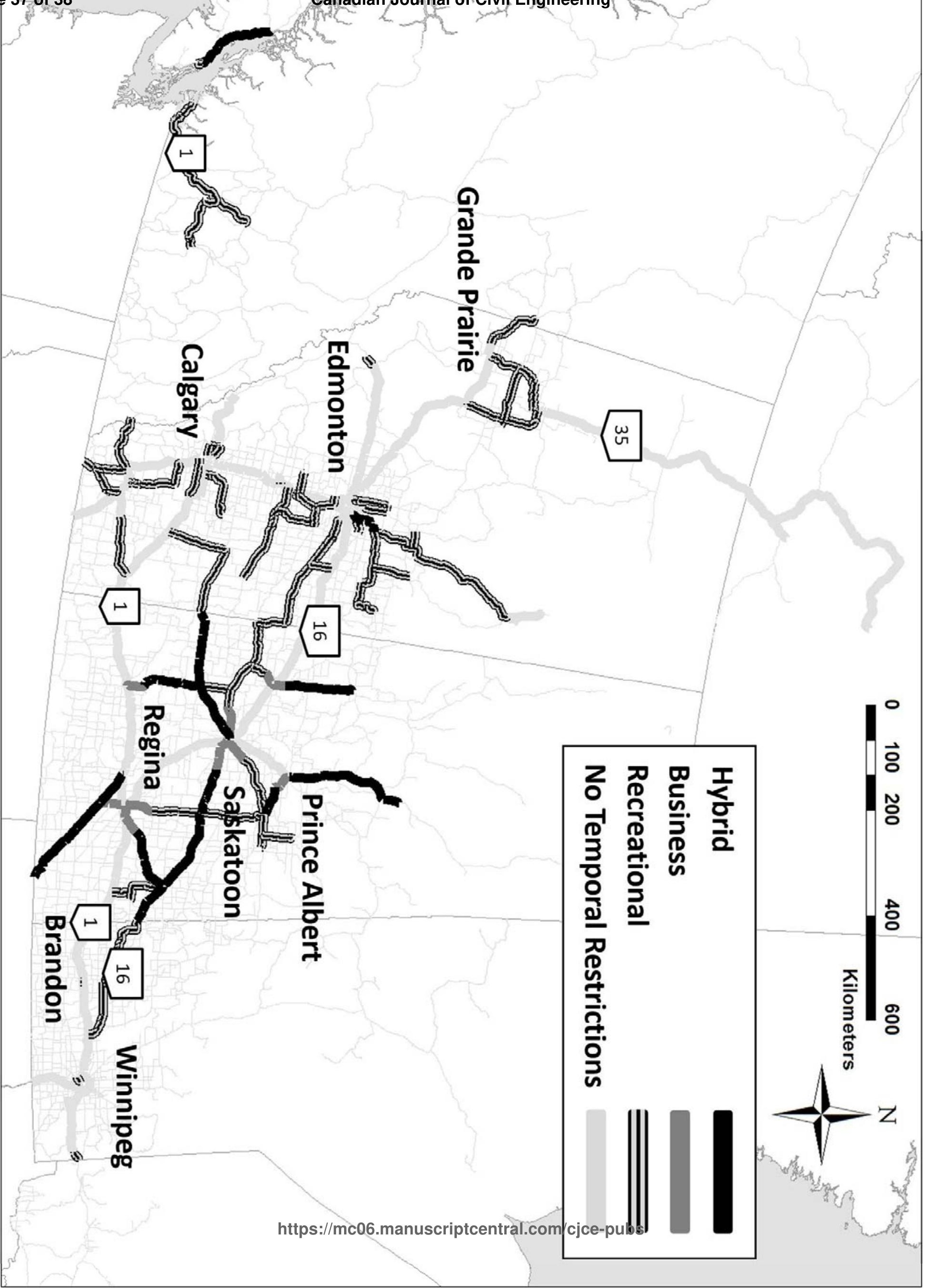




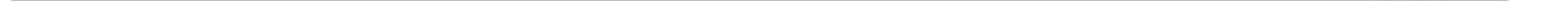

